\title{
İlköğretim Öğretmenlerinin Pozitif Psikolojik Sermaye Algıları Düzeylerinin Okul İklimi Üzerindeki Etkisinin İncelenmesi
}

DOI: 10.26466/opus.934995

\author{
$*$ \\ Ali Akdoğan * \\ * Dr, Uluslararası Final Üniversitesi, Eğitim Fakültesi, Girne/KKTC \\ E-Posta: $\underline{\text { akdoganali@hotmail.com }}$ \\ ORCID: $\underline{0000-0003-1498-4576}$
}

\begin{abstract}
Öz
Bu araştırma kapsamında ilköğretim kurumlarında görev yapan öğretmenlerin okul iklimi düzeyleri ve pozitif psikoloji sermaye algılarının belirlenmesi, bu iki değişken arasındaki ilişkinin incelenmesi ve yine bu iki değişken çeşitli bağımsız değişkenler doğrultusundaki farklılaşması incelenmiştir. Araştırma kapsamında gönüllülük esasına dayalı olarak 119 tane ilköğretim öğretmenine ulaşılmıştır. Araştırma kapsamında katılımcılardan iki farklı ölçme aracı üzerinden veri toplanmıştır, bunlar; (1) Okul İklimi Ölçeği ve (2) Pozitif Psikolojik Sermaye Ölçeğidir. Yapılan araştırma sonucuna göre, ilköğretim kurumlarında görev yapan öğretmenlerin okul iklimi alglarının yüksek olduğu söylenebilir ( $X=91.54)$.Okul iklimi algısının öğretmenlerin, cinsiyet, yaş, görev süresi ve branşlarına göre farklılaşmamaktadır. Bununla birlikte, ilköğretim kurumlarında görev yapan öğretmenlerin pozitif psikolojik sermaye algz düzeylerinin yüksek olduğu söylenebilir ( $X^{=}=94.58$ ). Bu çalışmada, ilköğretim kurumlarında görev yapmakta olan öğretmenlerin pozitif psikolojik sermaye düzeyleri demografik değişkenlere göre anlaml bir fark göstermemiştir. İlköğretim kurumlarında görev yapan öğretmenlerin okul iklimi algılar ile pozitif psikolojik sermaye algıları arasındaki ilişkinin belirlenebilmesi amacıyla Pearson momentler çarpımı korelasyon katsayısı hesaplanmıştır. Hesaplama işlemine geçilmeden önce normallik, doğrusallık ve eş varyanslılık varsayımları kontrol edilmiştir. Yapılan analiz sonucunda ilköğretim öğretmenlerinin okul iklimi algıları ile pozitif psikolojik sermaye algıları arasında anlamlı bir ilişki olmadı̆̆ı görülmüş̧ür, $r=.198, n=78, p=.081$.
\end{abstract}

Anahtar Kelimeler: Okul Iklimi, Pozitif Psikolojik Sermaye, Örgütsel Verimlilik, Öğrenci Başarısı, Ilköğretim Öğretmenleri. 


\title{
The Predictive Power of Positive Psychological Capital on School Climate: Primary Teachers' Examination
}

\begin{abstract}
The study aimed to investiagate the school cilmate and its relationship to positive psychological capital among primary school teachers. The study was conducted to determine whether primary school teachers develop their school climate, and whether school climate would increase positive psychological capital levels. The participants of the study were composed of 114 primary school teacher were selected randomly around Istanbul. The data were based on quantitative data. For the data analysis Pearson Product-Moment Correlation, and a series of ANOVA test were utilized. The results revealed that there was no a pozitif significant correlation between percieved school climate and positive psychological capital $(r=.198, n=78, p=.081)$. Meanwhile, the study showed that primary school teachers' school climate perception and positive psychological capital perceptions were high ( $X=94.58$ ). In addition, there was no significant difference between positive psychological capital perceptions of primary school teachers and demographic variables.
\end{abstract}

Keywords: School Climate, Positive Psychological Capital, Organizational Efficacy, Academic Achievement, Primary School Teachers. 


\section{Giriş}

Eğitimciler yüzyıllardır okul iklimi hakkında bilgi sahibidir. Buna karşın, 1950 yıllarına kadar okul iklimi konusunda sistematik bir çalışma yapılmamıştır. Söz konusu yılları takiben bilimsel olarak okul ikliminin eğitim öğretim ortamları içerisindeki etkisinin incelenmesi çalışmaları ile başlayan süreç günümüzde okul iklimi değerlendirme araçlarının geliştirilmesi ile devam etmektedir. Okul iklimini tanımlayacak evrensel bir tanım bulunmamaktadır. Araştırmacılar ve uygulayıcılar, okul iklimini pozitif atmosfer, duyguların tonu ve ortak değerler ortamı olarak tanımlamaktadır (Freiberg,1999; Homana,2006). Bununla birlikte, bazı araştırmacılara göre, okul iklimi öznel bağlam içerisinde değerlendirilirken bazı araştırmacılara göre ise okul yaşamının nesnel yüzeyi olarak değerlendirilmektedir (Torney,2006; Barber,2006).100 yıl önce Perry (1908) tarafından ilk olarak incelenmeye başlayan okul iklimi çalışmaları, okul ikliminin öğrencilerin öğrenme süreçleri üzerindeki olumlu etkilerini ileri sürmüştür. Okul ikliminin sosyal temelleri üzerine değerlendirmelerde bulunan Dewey'e (1927) göre ise okul iklimi, okul yaşamının sosyal bir boyutu olarak ifade edilmiştir. Ona göre, demokratik vatandaşlar yetişmek için dolaylı yoldan yapılan bilgi, beceri ve önlem müdahaleleri sosyal çevre ya da iklimin birer yansıması olarak okul yaşamının kendine has okul iklimini oluşturmasını desteklemektedir.

19. Yüzyılın başlarında okul iklimi konusunda yapılan çalışmalar çoğunlukla durum çalışması niteliği taşımakta idi. Buna karşın, 19 yüzyılın sonlarına doğru okul iklimi deneysel araştırmaların konusu olmuştur. Buna göre, okul ikliminin öğrencilerin kişisel gelişim süreçleri ve öğrenmeleri üzerindeki etkisinin değerlendirildiği deneysel bir çalışmada sonucu planlı ve sistemli olarak yapılandırılan pozitif okul iklimi faaliyetlerinin öğrencilerin kişisel gelişim süreçlerine ve öğrenmelerine olan ileri sürülmüştür (Haphin ve Croft (1963). Bununla beraber, diğer bir deneysel çalışmada, okul ikliminin etkili okul özelliklerinin oluşumu ve gelişimi üzerinde olumlu etki yarattığı saptanmıştır (Anderson, 1982). Öğretmenlerin, pozitif geri bildiriminin öğrencilerin öz yeterlilik algıları üzerindeki etkisinin incelendiği diğer bir çalışmada ise istikrarlı pozitif geri bildirimin öğrencilerin öz yeterlilik algılarını pozitif olarak etkilediği ileri sürülmüştür (Hoge, Smith ve Hanson, 1990). 
Sosyal ve duygusal okul ikliminin öğrencilerin psikiyatrik problemlerinin ve alkol kullanımı üzerindeki etkisinin, veli raporları doğrultusunda incelendiği çalışmada veli raporları, sosyal ve duygusal okul ikliminin öğrencilerin psikiyatrik problemlerinin ve alkol kullanma eğilimlerinin belirleyicisi olduğu ifade edilmiştir (Kasen, Johnson ve Cohen, 1990). Güvenli, destekleyici ve kapsayıcı okul ikliminin öğrencilerin, sosyal, duygusal ve akademik öğrenmeleri üzerindeki pozitif etkisinin incelendiği çalışmalar sonucunda güvenli, destekleyici ve kapsayıcı okul ikliminin öğrencilerin sosyal, duygusal ve akademik öğrenmeleri üzerindeki pozitif etkisi saptanmıştır (Osterman, 2000; BlumMcNeely ve Rinehart, 2002). Bununla birlikte, okul ikliminin öğrencilerin öğrenme motivasyonuna etkisinin incelendiği çalışmalar sonucunda pozitif okul ikliminin öğrencilerin öğrenme motivasyonu üzerindeki pozitif etkisi ileri sürülmüştür. Buna göre, pozitif bir okul iklimi içerisinde öğrencilerin öğrenmeye karşı motivasyonlarının arttığı ve derslere katılım oranlarında artış gözlemlenmiştir (Torney ve Purta, 2002; Homana, 2006).

Pozitif okul iklimi öğretmenlerim öğretim performanslarındaki pozitif etkisinin gözlemlendiği diğer bir çalışmada ise, verimli ve etkili öğretim performansının öğrencilerin akademik başarıları üzerindeki etkisi saptanmıştır (Talbert,2002).Pozitif okul ikliminin, risk önleme faaliyetleri, öğrenme ve öğretme ortamlarında etkin ve etkili uygulamalar üzerindeki pozitif etkisinin incelendiği çalışmalarda risk önleme çalışmaları, etkin ve etkili öğrenme ve öğretim uygulamaları ile güvenli, destekleyici, kapsayıcı ve teşvik edici okul iklimi arasında pozitif ilişki saptanmıştır (Cohen, 2001; Greenberg, 2003; Berkowitz ve Bier, 2005). Son yüzyılda ise araştırmacılar, okul iklimini niteleyen renk ve biçim ikileminde dört ana indikatör tanımlamıştır. Buna göre, okul yaşamının niteliğini oluşturan indikörler şu şekilde tanımlanmıştır: (a)güvenlik, (b)öğrenme -öğretme, (c)ilişki yönetimi, (d)çevresel yapılanma (Cohen, 2006). Okul iklimini niteliğini tanımlayan dört ana boyut ve boyutlar ile ilişkin tanımlayıcılar Tablo 1 de özetlenmiştir. 
Tablo 1. Okul ikliminin Niteliğini Tanımlayan Dört Ana Boyut ve Boyutlara İlişkin Tanimlayıcılar (Cohen,2006).

\begin{tabular}{|c|c|}
\hline Güvenlik & $\begin{array}{l}\text { Kriz planları, açık iletişim kuralları, etkili ve tutarlı ihlal dönütleri, okul içerisinde tutum } \\
\text { ve davranış ihlaller karşısında fiziksel güvenlik sağlanması } \\
\text { Bireysel farklılıklara saygı, ergen ve çocuklar arasındaki zorbalığın önlenmesi, çatışma } \\
\text { çözümleme becerisinin tüm okul paydaşları tarafından geliştirilmesi }\end{array}$ \\
\hline Öğrenme ve & Öğrenci başarısı üzerinde üst düzey hedeflerin belirlenmesi, öğrenme stillerine göre \\
\hline Öğretme & $\begin{array}{l}\text { farklılaştırılmış öğretim faaliyetlerinin yürütülmesi, öğret imsel liderlik ve yaratıcılık faali- } \\
\text { yetlerinin öğretim uygulamalarına sindirilmesi, gerçek yaşam ile ilişkin ögretim matery- } \\
\text { allerinin kullanılması } \\
\text { Disiplinler arası veya disiplinler üstü program geliştirme modellerinin geliştirilerek } \\
\text { öğrencilerin, sosyal, duygusal ve akademik gelişimlerinin bir bütün olarak destekleyen } \\
\text { öğretim programlarının geliştirilmesi } \\
\text { Okul çalışanlarının profesyonel gelişim ihtiyaçlarının belirli standartlar doğrultusunda } \\
\text { sürekli ve kademeli olarak karşılanması } \\
\text { Liderlik tarzlarının iletişime açık, destekleyici ve saygı uyandıran bir biçimde sergilenmesi }\end{array}$ \\
\hline İlişki Yönetimi & $\begin{array}{l}\text { Pozitif yetişkin-yetişkin ilişkilerinin (öğretmen-öğretmen, öğretmen-öğrenci, öğrenci- } \\
\text { yönetici, yönetici-öğretmen, yönetici-yönetici, öğretmen-veli, veli-yönetici), pozitif } \\
\text { öğrenci-öğrenci ilişkilerinin (ergen-ergen, çocuk-ergen, çocuk-çocuk) belirli bir disiplin } \\
\text { içerisinde yürütülmesi, etkili akademik planlama, işbirlikçi öğrenmenin desteklenmesi, } \\
\text { şiddet, ihlal ve zorbalığa karşı koruma önlem çalışmalarının yürütülmesi } \\
\text { Okul paydaşları arasındaki karşılıklı iletişimin destekleyici ve istikrarlı bir biçimde } \\
\text { sağlanması } \\
\text { Örgütsel aidiyet duygusunun okul toplumu içerisinde canlandırılmasının sağlanması }\end{array}$ \\
\hline $\begin{array}{l}\text { Fiziksel } \\
\text { Yapılanma }\end{array}$ & $\begin{array}{l}\text { Temizlik, uygun öğrenme ve öğretme ortamı ve materyalleri, estetik kalite, okul } \\
\text { büyüklüğü, müfredat dışı faaliyetlerin destekleyici öğrenme ortamları }\end{array}$ \\
\hline
\end{tabular}

Atmosferin canlı yaşamının devamını sağlayan bir nitelik taşıması gibi okul iklimi de tıpkı atmosfer gibi okul yaşamının devamını sağlayacak bir ortamın oluşturulmasını ifade eder. Okul iklimi konusunda yapılan çalışmalar incelendiğinde okul ikliminin tüm okul paydaşları üzerindeki etkisini gözlemlemek mümkündür. Okul ikliminin etkisi üzerinde yapılan çalışmalar oldukça fazladır. Buna karşın, okul iklimini etkileyen değişkenler üzerinde yapılan çalışmalar oldukça sinırlıdır. $\mathrm{Bu}$ nedenle, bu çalışmada, öğretmenlerin psikolojik sermaye algılarının okul ikilimi üzerindeki etkisinin incelenmesi amaçlanmıştır.

Psikolojik sermaye diğer bir ifade ile "psikolojik kapital" olarak son yıllarda literatürde konu alanı olan psikolojik sermaye, öz güven, iyimserlik, umut ve dayanıklılığ 1 kapsayan pozitif örgütsel davranışlar bütünü olarak ifade edilebilir (Luthans, Youssef ve Avolio, 2007). Psikolojik sermaye kavram olarak ilk olarak Martin Seligman (2002) tarafindan yayımlanan "Özgün Mutluluk" (Authentic Happiness) kitabında bir soru ile karşılık bulmuştur. Seligman (2002), insanın psikolojik olarak bir kapitali var mıdır? Sorusunu şayet var ise öyle ise nedir? nasıl sahip 
olunabilir? Soruları ile cevaplamıştır. Ardından, pozitif psikoloji bakış açısı ile pozitif psikolojik sermaye, Luthans $(2002 a, b)$ tarafından "Pozitif Örgütsel Davranış (pozitive organizational behavior, POB)" olarak sinıflandırılmıştır.

Buna göre, pozitif psikolojik sermaye ölçülebilir, gelişime açık ve çalışma performansını yönetebilen ve günümüz iş dünyasında verimliliğ $i$ ve çalışma performansının belirleyicisidir. Psikolojik sermayeyi kapsayan pozitif örgütsel sermaye şu şekilde ifade edilmiştir ( Luthans, 2002; Youssef ve Avolio, 2007)

1.Özgüven. Özgüven olarak tanımlanan ilk psikolojik sermaye bireylerin, planlanmış görevleri belirlenen bağlam içerisinde başarılı bir biçimde tamamlamasına katkıda bulunan kişisel kanaatleridir. Psikolojik sermaye kapasitesi olarak öz güven ile çalışma performansı arasında pozitif ve anlamlı bir ilişkinin bulunduğunu savunan Bandura'ya (1997) göre, örgütsel verimlilik ile çalışanların öz güven algıları arsında anlamlı bir ilişki bulunmaktadır. Buna göre, özgüven algısı yüksek olan çalışanların karmaşık ve zorlayıcı görevlerin üstesinden gelme eğilimlerinin özgüven algısı daha düşük çalışanlara göre daha yüksek olduğu ileri sürülmüştür.

2.Umut. İkinci olarak tanımlanan psikolojik sermaye kapasitesidir. Umut, bireyin interaktif olarak başarı duygusu ile pozitif olarak kendini güdülemesi olarak ifade edilebilir. Başarı duygusu (a) hedef odaklı kişisel faaliyetleri ve (b) amaçlara ulaşmak için planlanan yolları kapsamaktadır (Snyder, 1991). Umut, her ne kadar diğer pozitif duygu durumları ile eş değer olarak kabul edilse bile teorik olarak kavramsal bağımsızlık ve ayırt edici geçerliliği nedeni ile ölçülebilir nitelik taşımaktadır. Yola çıkma gücü olarak tanımlanan umut, diğer pozitif duygu durumlarının oluşmasında güdüleyici bir rol alır. Bu nedenle, umut, psikolojik sermaye kapasitesi olarak kabul edilmektedir. Yapılan araştırmalarda, umut ile akademik ve atletik başarı arasında pozitif bir ilişki saptanmıştır (Adams, 2003). Bununla beraber, başarmanın güdüleyicisi olarak olarak umut, iş başındaki verimliliği pozitif yor dalamıştır (Peterson ve Luthans, 2003).

3.İyimserlik. Seligman'ın (2002), iyimserlik yaklaşımı psikolojik sermayeyi kapsayan bütün duygu durumları ile yakından ilişkilidir. İyimserlik, kişisel olarak iyi veya kötü durumları açımlama tarzıdır. Bu noktada, daimi ve sürekli olarak hissedilen iyimserlik, bireyin genellikle kötü 
durumlar ile başa çıkarken içsel bir güdüleyici olarak kullandığ duygu durumudur. İyimserlik, iş yaşamında karşılaşılan zorlukların ve problemlerin çözümlenmesi için gerekli bir psikolojik sermayedir. İyimserlik üzerinde yapılan çalışmalar sonucunda iyimserlik algısı yüksek çalışanların çalışma performanslarının ve terfi olanaklarının diğer düşük olanlara göre daha yüksek olduğu saptanmıştır (Seligman, 2018).

4.Dayanıklılık. Her ne kadar Çocuk Psikopatolojisi pozitif psikolojinin dayanak noktası olarak kabul edilse de son yıllarda pozitif psikoloji kapsamında dayanıklılık organizasyon el davranış ve insan kaynakları yönetimini içerisinde değerlendirilmeye çalışılmıştır. Günümüzün zorlayıcı ve problemli iş yaşamındaki dramatik değişimler bireylerin, zorlayıcı problem durumları karşısında dayanıklılık kapasitesine sahip olmasını gerekli hale getirmiştir. Dayanıklılık kapasitesinin sınırlı sayıda bireyde var oluşunun ileri sürülmesinin ardından Masten (2001), birey ve toplum içerisindeki insan kapitalinin dayanıklılık kapasitesinin sınırlı sayıda olmadığını ileri sürmüştür. Ona göre, dayanıklılığın kişisel bir büyüsü yoktur. Dayanıklılık, günlük iş yaşamında karşılaşılan kuralcı, problemli ve zorlayıcı durumların içerisinde destekleyici bir yeterlilik alanı olarak bireyler tarafından dolaylı olarak geliştirilmektedir. $\mathrm{Bu}$ nedenle, her bir bireyin kendine özgü bir dayanıklılık kapasitesi vardır. Bununla beraber, Coutu (2002); dayanıklı birey profilini (a) gerçeği olduğu gibi kabullenebilen, (b) yaşamın var olan değerler ile örtük olduğuna derin bir inanç duyabilen ve (c) değişime karşı uyum sağlayabilen olarak tanımlamıştır. Buna göre, stres ile baş edebilme becerisi, tanımlanan söz konusu dayanıklı birey profilinde liderlerin, yöneticilerin ve çalışanların problemli ve zorlayıcı durumlar karşısında dayanıklılığı destekleyen bir beceri olarak ifade edilmiştir. Bununla birlikte, yapılan klinik deneyler ve pozitif psikoloji çalışmaları sonucunda dayanıklı birey profilin de tanımlanan üç bireysel yetkinliğin, psikoloji sermaye ve hedeflenen çalışma performansı üzerinde pozitif etkisi olduğu ileri sürülmüştür (Coutu, 2002).

Yapılan çalışmalar sonucunda, psikolojik sermaye algısı yüksek olan öğrencilerin akademik performanslarının daha yüksek olduğu saptanmıştır (Luthans, Luthans ve Jensen, 2012 ve Malone, 2010). Bununla beraber, Yapılan çalışmalar sonucunda, psikolojik sermaye algısı yüksek olan bireylerin zorluklarla mücadele etme eğilimlerinin psikolojik 
sermaye alg1sı düşük olan bireylere göre daha yüksek olduğu ileri sürülmüştür (Khan, Siraj ve Li, 2011). Yapılan çalışmalar sonucu, psikolojik sermaye ile öznel iyi oluş hali arasında pozitif bir korelasyon gözlemlenmiştir (Qingquan ve Zongkui, 2009).

Okul ikliminin etkisi üzerinde yapılan çalışmalar oldukça fazladır. Buna karşın, okul iklimini etkileyen değişkenler üzerinde yapılan çalışmalar oldukça sınırlıdır. Pozitif okul iklimi, tüm okul paydaşlarının ortak tutum, değer ve davranışları doğrultusunda oluşabilecek bir bağlamdır. Söz konusu bağlam içerisinde, tüm okul paydaşları ile doğrudan sosyal bir ilişki içerinde bulunan öğretmenlerin psikoloji sermaye algılarının yüksek olması onların, özgüven, umut, iyimserlik ve dayanıklılık algılarının da yüksek olması anlamına gelmektedir. Dolayısı ile psikolojik sermaye algısına sahip olan öğretmenlerin pozitif okul iklimi oluşturulmasına katkı sağlayacağı düşünülmektedir. Bu çalışmada, ilköğretim kurumlarında görev yapmakta olan öğretmenlerin okul iklimi düzeyleri ve psikoloji sermaye algı düzeylerinin belirlenmesi, bu iki değişken arasındaki ilişkinin incelenmesi ve yine bu iki değişken çeşitli bağımsız değişkenler doğrultusundaki farklılaşması incelenmesi amaçlanmaktadır. Bu çalışma, ilköğretim öğretmenlerinin okul iklimi düzeyleri ile psikoloji sermaye alg1 düzeyleri arasında bir ilişki vardır hipotezi üzerine kurulmuştur. $\mathrm{Bu}$ çalışmada, aşağıdaki alt problemlere cevap aranacaktır.

1. İlköğretim Kurumlarında Görev Yapan Öğretmenlerinin Okul İklimi Algı Düzeyi Nasıldır?

2. İlköğretim Kurumlarında Görev Yapan Öğretmenlerin Psikolojik Sermaye Algı Düzeyleri Nasıldır?

3. İlköğretim Kurumlarında Görev Yapan Öğretmenlerin Okul İklimi Puanlarını Çeşitli Değişkenlere Göre Farklılaşmakta mıdır?

4. İlköğretim Kurumlarında Görev Yapan Öğretmenlerin Psikolojik Sermaye Puanlarını Çeşitli Değişkenlere Göre Farklılaşmakta midir?

5. İlköğretim Kurumlarında Görev Yapan Öğretmenlerin Okul İklimi Alg1 Puanları ile Psikolojik Sermaye Puanları Arasındaki Bir İlişki Var mıdır? 


\section{Yöntem}

\section{Araştırma Modeli}

$\mathrm{Bu}$ araştırma kapsamında ilköğretim kurumlarında görev yapan öğretmenlerin okul iklimi düzeyleri ve pozitif psikoloji sermaye algılarının belirlenmesi, bu iki değişken arasındaki ilişkinin incelenmesi ve yine bu iki değişken çeşitli bağımsız değişkenler doğrultusundaki farklılaşması incelenmiştir. Alan yazından bir gruba ait çeşitli özelliklerin ortaya konulması için gözlem yapılmasını kapsayan araştırmalar tarama araştırmaları olarak anılmaktadır. Bu özellikler ile ilgili gözlem yapıldıktan yani veri toplandıktan sonra çeşitli başka değişken veya özelliklerle ilişkisini inceleyen araştırmalara da ilişkisel (associational) araştırma ismi verilmektedir. Bu iki tanım göze alındığında bu çalışma ilişkisel düzeyde bir tarama araştırması veya sık kullanılan şekliyle ilişkisel tarama araştırması olarak ifade edilebilir (Büyüköztürk ve diğerleri, 2016).

\section{Çalışma Grubu}

Araştırma kapsamında gönüllülük esasına dayalı olarak 119 tane ilköğretim öğretmenine ulaşılmıştır. Katılımcıların 103 tanesi kadın ve 16 tanesi erkektir. Katılımcıların yaş ortalaması 35.10 olarak e katılımcıların mesleki deneyimleri de ortalama 10.93 yıl olarak hesaplanmıştır. Katılımcıların eğitim durumları incelendiğinde ise 100 kişinin Ön Lisans ve Lisans düzeyinde ve 19 kişinin de lisansüstü düzeyinde eğitime sahip oldukları görülmüştür.

\section{Veri Toplama Araçları}

Araştırma kapsamında katılımcılardan iki farklı ölçme aracı üzerinden veri toplanmıştır, bunlar; (1) Okul İklimi Ölçeği ve (2) Pozitif Psikolojik Sermaye Ölçeğidir.

Okul İklimi Ölçeği: Canlı, Demirtaş ve Özer (2018) tarafından geliştirilen ölçek öğretmenlerin okul iklimine karşı algılarına dayanmaktadır. Ölçek 
geliştirme çalışmasından ilk olarak alan yazın taraması yapılarak 69 madde yazılmıştır. İlk olarak maddelerde belirtilen ifadelerin anlaşılırlığ1 ile ilgili olarak uzman görüşü alınmış ve bu doğrultuda 27 madde, madde havuzundan çıkartılmış ve 42 madde kalmıştır. Ölçek beşli likert tipindedir ve (1) Hiçbir Zaman, (2) Nadiren, (3) Bazen, (4) Çoğunlukla ve (5) Her zaman ifadeleriyle katılımcılara uygulanır. Ölçeğin 42 maddelik ilk uygulaması sonucunda ölçeğin maddelerinin ilgili yapıya uygunluğunun test edilmesi için AFA uygulanmıştır. Yapılan uygulama sonucunda 5 ölçeğin 5 faktörlü bir yapıya sahip olduğu görülmüştür. Bu faktörler; "demokratiklik ve okula adanma", "liderlik ve etkileşim", "başarı etkenleri", "samimiyet" ve "çatışma" olarak isimlendirilmiştir. Açımlayıcı faktör analizi sonucunda 18 maddenin ölçekten çıkartılmasına karar verilmiştir ve ölçek 24 maddelik formuyla toplam varyansın \%67.82'sini açıklamıştır. Bu işlemin ardından Doğrulayıcı faktör analizine geçilmiştir. Doğrulayıcı faktör analizinde 14.maddenin t değerinin 1.96' dan düşük olması nedeniyle 14.madde de çıkartılmıştır ve ölçek 23 maddelik son şeklini almıştır. Doğrulayıcı Faktör Analizi sonuçlarında uyum indeksleri incelendiğinde uyum indekslerinin genel olarak kabul edilebilir seviyede olduğu görülmüştür ( $\chi^{2} /$ sd: 3.08, GFI..91, AGFI: .88, NNFI:.92, CFI:.93, RMSEA:.059, RMR:0.57). Bu işlemlerin ardından güvenirlik çalışmaları kapsamında iç tutlarlılık bağlamında Cronach'ın alfa katsayısı kullanılmıştır ve "demokratiklik ve okula adanma" alt boyutu için .908, "liderlik ve etkileşim" alt boyutu için .897, "başarı etkenleri" alt boyutu için .753, "samimiyet" alt boyutu için .852 ve çatışma alt boyutu için .730 olarak hesaplanmıştır. Ölçeğin kararlılık anlamında güvenirliğini belirlemek amacıyla test-tekrar test yöntemi kullanılmış ve iki uygulama arasındaki ilişki Pearson Momentler Çarpımı Korelasyon Katsayısı ile belirlenmiştir. Yapılan analiz sonucunda iki uygulama arasında her bir alt boyut için hesaplanan korelasyon katsayılarının tamamının .70'in üzerinde olduğu hatta en düşük değerin .826 olduğu görülmüştür. Tüm bu sonuçlar doğrultusunda ölçeğin geçerli ve güvenilir bir ölçek olduğuna karar verilmiş ve araştırma kapsamında kullanılmıştır.

Pozitif Psikolojik Sermaye Ölçeği: Araştırma kapsamında kullanılan bir diğer ölçek ise Luthans (2007) tarafından geliştirilen ve Akçay (Akçay, 
2014) tarafından Türkiye kültürüne uyarlanmış olan ölçek öncelikle orijinal dili olan İngilizce'den Türkçe'ye çevrilmiştir.24 maddeden oluşan ölçek yapılan faktör analizi sonucunda 4 faktörlü orijinal yapısını sağlamıştır. Güvenirlik kanıtı olarak da test tekrar test yöntemi üç farklı uygulama yapılarak gerçekleştirilmiş. Yapılan uygulamalar arasında 0.82 ile 0.93 değerleri arasında değiştiği görülmüştür. Ölçeğin iç tutarlılık katsayısı olarak hesaplanan Cronbach alfa katsayısı ise 0.97 olarak belirlenmiştir. Bu sonuçlar göz önüne alındı̆̆ında ölçeğin araştırmada kullanımının uygun olduğuna karar verilmiştir.

\section{İşlem}

Araştırma kapsamında ilköğretim kurumlarında görev yapan 119 adet öğretmene ulaşılmıştır ve bu öğretmenlere Okul İklimi Ölçeği ve Pozitif Psikolojik Sermaye Ölçeği uygulanmıştır. Yapılan uygulama sonucunda elde edilen verilerde ilk olarak kayıp veri elde edilip edilmediği incelenmiştir ve herhangi bir kayıp verinin olmadığı görülmüştür. Bir sonraki aşamada elde edilen verilerde uç değer taraması yapılmıştır. Uç değer tarması iki aşamalı olarak yapılmıştır. İlk aşamada madde puanları standart $\mathrm{z}$ puanlarına dönüştürülmüş ve $|z|$ değerlerinin \pm 3 aralığında olup olmadığı incelenmiştir. Bu değerinde dışında kalan katılımcıların uç değer gösterdikleri kabul edilmiştir (Kline, 2016). Yapılan inceleme sonucunda Okul İklimi Ölçeği maddelerinde toplam 11 kişinin ve Pozitif Psikolojik Sermaye Ölçeği'nde ise 17 kişinin tek yönlü uç değer gösterdiği belirlenmiştir ve bu kişiler veri setinden çıkartılmıştır. Bu işlemin ardından kalan 91 kişilik veri seti ile çok yönlü uç değer taramasına geçilmiştir. Çok yönlü uç değer taraması Mahalanobis uzaklığı $(D)$ ile gerçekleştirilmiştir. Bu yaklaşımda uç değerler $\chi^{2}$ değerleri ile belirlenir ve daha katı bir anlamlılık düzeyi belirlenmesi önerilir bu nedenle de bu araştırmada Mahalanobis uzaklığı için $\chi^{2}$ anlamlılık değeri madde sayısının serbestlik derecesi olduğu durumda .001 olarak belirlenmiştir (Kline, 2016). Yapılan çok yönlü uç değer taramasında Okul İklimi Ölçeği için serbestlik derecesi 23 olarak belirlenmiştir ve 4 kişi uç değer olarak tespit edilmiştir ( $\chi^{2}(23)=41.638$, p<.001.); Pozitif Psikoloji Sermaye Ölçeği için serbestlik derecesi 24 olarak belirlenmiş̧ir ve 9 kişi uç değer olarak tespit edilmiştir $\left(\chi^{2}(24)=42.980, \mathrm{p}<.001\right.$.). Yapılan işlemlerin ardından veri 
seti 78 ilköğretim öğretmeninin verisinden oluşmaktadır. Son durumda çalışma grubunun durumu Tablo 2' de verilmiştir.

Tablo 2. Çıkartılan Uç Değerler Sonrasında Okul İklimi Ölçeği ve Pozitif Psikolojik Sermaye Ölçeği Demografik Bilgilerine İlişkin Bilgiler

\begin{tabular}{llll}
\hline Değişken & Alt Grup & N & $\%$ \\
\hline Cinsiyet & Kadın & 66 & 84.6 \\
& Erkek & 12 & 15.4 \\
Yaş & $20-39$ & 54 & 69.2 \\
Eğitim Düzeyi & $40-64$ & 24 & 30.8 \\
& Ön lisans -Lisans & 67 & 85.9 \\
Branş & Lisansüstü & 11 & 14.1 \\
& Okul Öncesi ve Sınıf Öğret- & 40 & 51.3 \\
& menliği & 38 & 48.7 \\
Görev Süresi & Branş Öğretmenleri & 27 & 34.6 \\
& $1-5$ yll & 22 & 28.2 \\
Pozitif Psikoloji Eğitimi & 6-10 yıl & 13 & 16.7 \\
Alma Durumu & $11-15$ yıl & 16 & 20.5 \\
\hline
\end{tabular}

Araştırma kapsamında kullanılacak analizlerin varsayımlarından biri olan normallik varsayımı test etmek için hem ölçeklerin toplam puanları hem de "cinsiyet", "yaş", "eğitim düzeyi", "branş", "görev süresi" ve "pozitif psikoloji ile ilgili eğitim alma durumu" bağımsız değişkenleri için ayrı ayrı incelenmiştir ve çarpıklık ve basıklık katsayılarının tüm bu durumlarda \pm 1 aralığında olduğu görülmüştür. Ayrıca histogram grafikleri de incelenmiştir ve dağılımın normale yakın olduğu görülmüştür. Ek olarak Kolmogorov-Simirnov normallik testi yapılmış ve anlamlılık değerinin .20 olduğu ve anlamlı olmadığı bir başka ifade dağglımın standart normal dağılımdan anlamlı bir biçimde farklılaşmadığı görülmüştür ve tüm bu bilgiler ışığında dağılımın normale yakın olduğuna karar verilmiştir. Araştırma sorularında ifade edilen ilköğretim öğretmenlerinin okul iklimi algıları ve psikolojik sermaye düzeyleri arasındaki ilişkinin ortaya konuması için Pearson Momentler Çarpımı Korelasyon Katsayısı kullanılmıştır. İlköğretim öğretmenlerinin Okul İklimi Ölçeği toplam puanları ve pozitif psikolojik sermaye toplam puanlarının "cinsiyet", "yaş", "eğitim düzeyi", "branş" ve "pozitif psikoloji eğitimi alma durumlarına" göre farklılaşmasını incelemek için Bağımsız Örneklemler İçin T Testi, 
görev süresi değişkeni için Tek Yönlü Varyans Analizi (ANOVA) uygulanmiştır.

\section{Bulgular}

İlköğretim kurumlarında görev yapan öğretmenlerin okul iklimi algı dïzeyleri: Araştırma kapsamında ilköğretim kurumlarında görev yapan öğretmenlerin okul iklimi algi düzeyleri Okul İklimi Ölçeği ile ölçülmeye çalışılmıştır. Çalışmaya katılan öğretmenlerin okul iklimi algı ortalamaları $X^{-}=91.54$ olarak bulunmuştur. Daha ayrıntılı bir inceleme için bağımsız değişkenlere göre ilköğretim öğretmenlerinin okul iklimi alg1 düzeylerine ilişkin bilgiler Tablo 3'te verilmiştir.

Tablo 3. İlköğretim Kurumlarnnda Görev Yapan Öğretmenlerin Okul İklimi Algı Düzeyleri

\begin{tabular}{|c|c|c|c|c|c|}
\hline Değişken & Alt Grup & $\mathbf{N}$ & $\overline{\boldsymbol{X}}$ & SS & Ranj \\
\hline \multirow{2}{*}{ Cinsiyet } & Kadın & 66 & 91.09 & 10.29 & 53.00 \\
\hline & Erkek & 12 & 94.00 & 8.31 & 27.00 \\
\hline \multirow{2}{*}{ Yaş } & $20-39$ & 54 & 91.94 & 10.08 & 53.00 \\
\hline & $40-64$ & 24 & 90.63 & 10.02 & 38.00 \\
\hline \multirow{2}{*}{ Eğitim Düzeyi } & Ön lisans -Lisans & 67 & 91.73 & 11.17 & 34.00 \\
\hline & Lisansüstü & 11 & 91.73 & 11.17 & 34.00 \\
\hline \multirow[t]{2}{*}{ Branş } & $\begin{array}{l}\text { Okul Öncesi ve Sınıf } \\
\text { Öğretmenliği }\end{array}$ & 40 & 92.43 & 8.92 & 41.00 \\
\hline & Branş Öğretmenleri & 38 & 90.61 & 11.10 & 53.00 \\
\hline \multirow{4}{*}{ Görev Süresi } & $1-5$ yil & 27 & 94.48 & 10.78 & 41.00 \\
\hline & 6-10 yıl & 22 & 90.82 & 12.38 & 53.00 \\
\hline & $11-15$ yil & 13 & 88.69 & 6.66 & 24.00 \\
\hline & 16 yıl ve üzeri & 16 & 89.88 & 6.11 & 23.00 \\
\hline \multirow{2}{*}{$\begin{array}{l}\text { Duygusal Zekâ } \\
\text { Eğitimi Alma Du- } \\
\text { rumu }\end{array}$} & Evet & 18 & 92.78 & 9.60 & 34.00 \\
\hline & Hayır & 60 & 91.17 & 10.19 & 53.00 \\
\hline
\end{tabular}

İlköğretim kurumlarında görev yapan öğretmenlerin pozitif psikolojik sermaye algı dïzeyleri: Araştırma kapsamında ilköğretim kurumlarında görev yapan öğretmenlerin pozitif psikolojik sermaye algı düzeyleri Pozitif Psikoloji Ölçeği ile ölçülmeye çalışılmıştır. Çalışmaya katılan öğretmenlerin okul iklimi algı ortalamaları $\bar{X}=94.58$ olarak bulunmuştur. Daha ayrıntılı bir inceleme için bağımsız değişkenlere göre ilköğretim öğretmenlerinin okul iklimi algı düzeylerine ilişkin bilgiler Tablo 4'te verilmiştir. 
Tablo 4. Illköğretim Kurumlarında Görev Yapan Öğretmenlerin Pozitif Psikolojik Sermaye Algi Düzeyleri

\begin{tabular}{|c|c|c|c|c|c|}
\hline Değişken & Alt Grup & $\mathbf{N}$ & $\bar{X}$ & SS & Ranj \\
\hline \multirow{2}{*}{ Cinsiyet } & Kadın & 66 & 94.42 & 8.56 & 42.00 \\
\hline & Erkek & 12 & 95.42 & 6.92 & 20.00 \\
\hline \multirow{2}{*}{ Yaş } & $20-39$ & 54 & 93.35 & 8.61 & 42.00 \\
\hline & $40-64$ & 24 & 97.33 & 6.95 & 28.00 \\
\hline \multirow{2}{*}{ Eğitim Düzeyi } & Ön lisans -Lisans & 67 & 93.99 & 8.02 & 36.00 \\
\hline & Lisansüstü & 11 & 98.18 & 9.40 & 30.00 \\
\hline \multirow[t]{2}{*}{ Branş } & $\begin{array}{l}\text { Okul Öncesi ve Sınıf } \\
\text { Öğretmenliği }\end{array}$ & 40 & 93.48 & 8.23 & 33.00 \\
\hline & Branş Öğretmenleri & 38 & 95.74 & 8.31 & 34.00 \\
\hline \multirow{4}{*}{ Görev Süresi } & $1-5$ yil & 27 & 91.26 & 9.14 & 33.00 \\
\hline & 6-10 yıl & 22 & 96.64 & 7.50 & 31.00 \\
\hline & $11-15$ yıl & 13 & 95.46 & 8.23 & 24.00 \\
\hline & 16 yıl ve üzeri & 16 & 96.63 & 6.64 & 24.00 \\
\hline
\end{tabular}

Illöğretim kurumlarında görev yapan öğretmenlerin okul iklimi puanlarının cinsiyete göre farklılı̆̆ının incelenmesi: Araştırma kapsamında incelenen ilköğretim kurumlarında görev yapan öğretmenlerin okul iklimi puanlarının cinsiyete göre ortalamalar arasındaki farklılı̆̆ın istatistiksel olarak anlamlı olup olamdığını ortaya koymak amacıyla Bağımsız Örneklemler İçin T Testi yapılmıştır. İlköğretim kurumlarında görev yapan öğretmenlerin okul iklimi puanlarının cinsiyete göre t-testi sonuçları Tablo $5^{\prime}$ te verilmiştir.

Tablo 5. İlköğretim Kurumlarnnda Görev Yapan Öğretmenlerin Okul İklimi Puanlarının Cinsiyete Göre T-Testi Sonuçları

\begin{tabular}{|c|c|c|c|c|c|c|}
\hline Cinsiyet & $\mathbf{N}$ & $\overline{\mathbf{X}}$ & SS & sd & $t$ & $p$ \\
\hline Kadın & 66 & 91.09 & 10.29 & 76 & -0.924 & .358 \\
\hline Erkek & 12 & 94.00 & 8.31 & & & \\
\hline
\end{tabular}

Tablo 5 incelendiğinde, ilköğretim kurumlarında görev yapan öğretmenlerin okul iklimi puanları cinsiyete göre anlamlı bir farklılık göstermemektedir, $\mathrm{t}(76)=-0.924, \mathrm{p}=.358$.

İlköğretim kurumlarında görev yapan öğretmenlerin okul iklimi puanlarının yaş gruplarına göre farklılı̆̆ının incelenmesi: Araştırma kapsamında incelenen ilköğretim kurumlarında görev yapan öğretmenlerin okul iklimi puanlarının yaş gruplarına göre ortalamalar arasındaki farklılığın istatistiksel olarak anlamlı olup olamdığını ortaya koymak 
amacıyla Bağımsız Örneklemler İçin T Testi yapılmıştır. İlköğretim kurumlarında görev yapan öğretmenlerin okul iklimi puanlarının yaş gruplarına göre t-testi sonuçları Tablo 6'da verilmiştir.

Tablo 6. İlköğretim Kurumlarnnda Görev Yapan Öğretmenlerin Okul İklimi Puanlarının Yaş Gruplarnna Göre T-Testi Sonuçları

\begin{tabular}{|c|c|c|c|c|c|c|}
\hline Yaş Grupları & $\mathbf{N}$ & $\overline{\mathbf{X}}$ & SS & sd & $t$ & p \\
\hline $20-39$ & 54 & 91.94 & 10.08 & 76 & 0.534 & .595 \\
\hline $40-64$ & 24 & 90.63 & 10.02 & & & \\
\hline
\end{tabular}

Tablo 6 incelendiğinde, ilköğretim kurumlarında görev yapan öğretmenlerin okul iklimi puanları yaş gruplarına göre anlamlı bir farklılık göstermemektedir, $\mathrm{t}(76)=0.534, \mathrm{p}=.595$.

İlköğretim kurumlarında görev yapan öğretmenlerin okul iklimi puanlarının eğitim düzeylerine göre farklılığının incelenmesi: Araştırma kapsamında incelenen ilköğretim kurumlarında görev yapan öğretmenlerin okul iklimi puanlarının eğitim düzeylerine göre ortalamalar arasındaki farklılığın istatistiksel olarak anlamlı olup olamdığını ortaya koymak amacıyla Bağımsız Örneklemler İçin T Testi yapılmıştır. İlköğretim kurumlarında görev yapan öğretmenlerin okul iklimi puanlarının eğitim düzeylerine göre t-testi sonuçları Tablo 7'de verilmiştir.

Tablo 7. İlköğretim Kurumlarında Görev Yapan Öğretmenlerin Okul İklimi Puanlarının Eğitim Düzeylerine Göre T-Testi Sonuçları

\begin{tabular}{|c|c|c|c|c|c|c|}
\hline Ĕgitim Düzeyi & $\mathbf{N}$ & $\overline{\mathrm{X}}$ & SS & sd & $t$ & $\mathrm{p}$ \\
\hline Önlisans-Lisans & 67 & 91.51 & 9.91 & 76 & -.067 & .947 \\
\hline Lisansüstü & 11 & 91.73 & 11.17 & & & \\
\hline
\end{tabular}

Tablo 7 incelendiğinde, ilköğretim kurumlarında görev yapan öğretmenlerin okul iklimi puanları eğitim düzeylerine göre anlamlı bir farklılık göstermemektedir, $\mathrm{t}(76)=-0.067, \mathrm{p}=.947$.

İlköğretim kurumlarında görev yapan öğretmenlerin okul iklimi puanlarının öğretmenlerin branşlarına göre farklılı̆̆ının incelenmesi: Araştırma kapsamında incelenen ilköğretim kurumlarında görev yapan öğretmenlerin okul iklimi puanlarının öğretmenlerin branşlarına göre ortalamalar arasındaki farklılığın istatistiksel olarak anlamlı olup 
olamdığını ortaya koymak amacıyla Bağımsız Örneklemler İçin T Testi yapılmıştır. İlköğretim kurumlarında görev yapan öğretmenlerin okul iklimi puanlarının öğretmenlerin branşlarına göre t-testi sonuçları Tablo 8 'de verilmiştir.

Tablo 8. İlköğretim Kurumlarnnda Görev Yapan Öğretmenlerin Okul İklimi Puanlarının Öğretmenlerin Branşlarına Göre T-Testi Sonuçları

\begin{tabular}{|c|c|c|c|c|c|c|}
\hline Branş & $\mathbf{N}$ & $\overline{\mathbf{X}}$ & SS & sd & $t$ & $\mathrm{p}$ \\
\hline \multicolumn{7}{|c|}{ Okul Öncesi ve } \\
\hline $\begin{array}{l}\text { Sınıf Öğret- } \\
\text { menliği }\end{array}$ & 40 & 92.43 & 8.92 & 76 & .800 & .426 \\
\hline $\begin{array}{l}\text { Branş Öğret- } \\
\text { menleri }\end{array}$ & 38 & 90.61 & 11.10 & & & \\
\hline
\end{tabular}

Tablo 8 incelendiğinde, ilköğretim kurumlarında görev yapan öğretmenlerin okul iklimi puanları öğretmenlerin branşlarına göre anlamlı bir farkl1lık göstermemektedir, $\mathrm{t}(76)=0.800, \mathrm{p}=.426$.

İlköğretim kurumlarında görev yapan öğretmenlerin okul iklimi puanlarının öğretmenlerin görev sürelerine (deneyimlerine) göre farklılı̆̆ının incelenmesi: Araştırma kapsamında incelenen ilköğretim kurumlarında görev yapan öğretmenlerin okul iklimi puanlarının öğretmenlerin görev sürelerine (deneyimlerine) göre ortalamalar arasındaki farklılığın istatistiksel olarak anlamlı olup olamdığını ortaya koymak amacıyla tek yönlü varyans analizi (ANOVA) yapılmıştır. Varyansların homojenliği varsayımını test etmek için Levene homojenlik testi gerçekleştirilmiştir ve sonuçları Tablo 9a'da verilmiştir.

Tablo 9a. Öğretmenlerin Görev Sürlerine (Deneyimlerine) Göre Okul İklimi Puanlarının Levene Homojenlik Testi Sonuçları

\begin{tabular}{llll}
\hline Levene & sd1 & sd2 & p \\
\hline 3.295 & 3 & 74 & .025 \\
\hline
\end{tabular}

Tablo 9a incelendiğinde varyansların homojen oolmadığı görülmektedir, Levene=3.295, p=.025. Bu durum göz önüne alınarak Welch'in F testi kullanılmıştır (Pallant, 2016). Öğretmenlerin görev sürlerine (deneyimlerine) göre okul iklimi puanlarına ait betimsel istatistikler Tablo 2' de, görev sürelerine (deneyimlerine) göre farklılığ 1 gösteren Welch testi sonuçları Tablo 9b'de verilmiştir. 
Tablo 9b. Okul İklimi Puanlarının Öğretmenlerin Çalışma Sürelerine (Deneyimlerine) Göre Welch Sonuçları

\begin{tabular}{lllll}
\hline & İstatistik & sd1 & sd2 & p \\
\hline Welch & 1.544 & 3 & 38.633 & .219 \\
\hline
\end{tabular}

Analiz sonuçları, okul iklimi ortalama puanlarının öğretmenlerin görev süresi (deneyimi) bağımsız değişkenindeki alt gruplara (1-5 yıl, 610 yıl, 11-15 yıl, 16 yıl ve üzeri) göre farklılaşmasının istatistiksel anlamda anlamlı bir farklılaşma olmadığını göstermektedir, Weşch's $\mathrm{F}(3.38 .633)=1.544, \mathrm{p}=.163$.

İlköğretim kurumlarında görev yapan öğretmenlerin pozitif psikolojik sermaye puanlarının cinsiyete göre farklılığının incelenmesi:Araştırma kapsamında incelenen ilköğretim kurumlarında görev yapan öğretmenlerin pozitif psikolojik sermaye puanlarının cinsiyete göre ortalamalar arasındaki farklılığın istatistiksel olarak anlamlı olup olamdığını ortaya koymak amacıyla Bağımsız Örneklemler İçin T Testi yapılmıştır. İlköğretim kurumlarında görev yapan öğretmenlerin pozitif psikolojik sermaye puanlarının cinsiyete göre t-testi sonuçları Tablo $10^{\prime}$ da verilmiştir.

Tablo 10. İlköğretim Kurumlarında Görev Yapan Öğretmenlerin Pozitif Psikoljik Sermaye Puanlarınin Cinsiyete Göre T-Testi Sonuçları

\begin{tabular}{|c|c|c|c|c|c|c|}
\hline Cinsiyet & $\mathbf{N}$ & $\overline{\mathbf{x}}$ & SS & sd & $t$ & $p$ \\
\hline Kadın & 66 & 94.23 & 8.81 & 76 & $\begin{array}{l}-0.563 \\
\end{array}$ & .575 \\
\hline Erkek & 12 & 95.75 & 7.35 & & & \\
\hline
\end{tabular}

Tablo 10 incelendiğinde, ilköğretim kurumlarında görev yapan öğretmenlerin pozitif psikolojik sermaye puanlarının cinsiyete göre anlamlı bir farklılık göstermediği görülmüştür, $\mathrm{t}(76)=-0.924, \mathrm{p}=.358$.

İlköğretim kurumlarında görev yapan öğretmenlerin pozitif psikolojik sermaye puanlarının yaş gruplarına göre farklılı̆̆ını incelenmesi: Araştırma kapsamında incelenen ilköğretim kurumlarında görev yapan öğretmenlerin pozitif psikolojik sermaye puanlarının yaş gruplarına göre ortalamalar arasındaki farklılığın istatistiksel olarak anlamlı olup olamdığını ortaya koymak amacıyla Bağımsız Örneklemler İçin T Testi yapılmıştır. İlköğretim kurumlarında görev yapan öğretmenlerin pozitif 
psikolojik sermaye puanlarının yaş gruplarına göre t-testi sonuçları Tablo 11 'de verilmiştir.

Tablo 11. İlköğretim Kurumlarında Görev Yapan Öğretmenlerin Pozitif Psikolojik Sermaye Puanlarının Yaş Gruplarına Göre T-Testi Sonuçları

\begin{tabular}{|c|c|c|c|c|c|c|}
\hline Yaş Grupları & $\mathbf{N}$ & $\overline{\mathbf{X}}$ & SS & sd & $t$ & $p$ \\
\hline $20-39$ & 54 & 93.13 & 8.82 & 76 & -2.103 & .039 \\
\hline $40-64$ & 24 & 97.46 & 7.30 & & & \\
\hline
\end{tabular}

Tablo 11 incelendiğinde, ilköğretim kurumlarında görev yapan öğretmenlerin pozitif psikolojik sermaye puanları yaş gruplarına göre anlamlı bir farklılık göstermektedir, $\mathrm{t}(76)=-2.103, \mathrm{p}=.039, \eta^{2}=0.055$. İlköğretim öğretmenlerinin pozitif psikolojik sermaye puanlarının yaş gruplarına göre gözlemlenmiş olan ortamla farklılığı daha detaylı incelendiğinde, 4064 yaş grubundaki ilköğretim öğretmenlerinin $(\bar{X}=97.46), 20-39$ yaş grubundaki ilköğretim öğretmenlerine $(\bar{X}=93.13)$ göre daha yüksek pozitif psikolojik sermaye algısı puan ortalamasına sahip oldukları görülmektedir. Söz konusu farkın etki büyüklüğünü belirlemek amacıyla eta kare $\left(\eta^{2}\right)$ değeri hesaplanmıştır ve söz konusu etki büyüklüğünün "orta" düzeyde olduğu söylenebilir.

Illköğretim kurumlarında görev yapan öğretmenlerin pozitif psikolojik sermaye puanlarının eğitim düzeylerine göre farklılı̆̆ının incelenmesi: Araştırma kapsamında incelenen ilköğretim kurumlarında görev yapan öğretmenlerin pozitif psikolojik sermaye puanlarının eğitim düzeylerine göre ortalamalar arasındaki farklılığın istatistiksel olarak anlamlı olup olamdığını ortaya koymak amacıyla Bağımsız Örneklemler İçin T Testi yapılmıştır. İlköğretim kurumlarında görev yapan öğretmenlerin pozitif psikolojik sermaye puanlarının eğitim düzeylerine göre t-testi sonuçları Tablo 12'de verilmiştir.

Tablo 12. İlköğretim Kurumlarında Görev Yapan Öğretmenlerin Pozitif Psikolojik Sermaye Puanlarnnı Eğitim Düzeylerine Göre T-Testi Sonuçları

\begin{tabular}{|c|c|c|c|c|c|c|}
\hline Eğitim Düzeyi & $\mathbf{N}$ & $\overline{\mathbf{X}}$ & SS & sd & $t$ & $\mathrm{p}$ \\
\hline Önlisans-Lisans & 67 & 93.76 & 8.26 & 76 & -1.807 & .075 \\
\hline Lisansüstü & 11 & 98.73 & 9.63 & & & \\
\hline
\end{tabular}


Tablo 12 incelendiğinde, ilköğretim kurumlarında görev yapan öğretmenlerin pozitif psikolojik sermaye puanları eğitim düzeylerine göre farklılaşmasının istatistiksel olarak anlamlı bir farklılık olmadığı görülmektedir, $\mathrm{t}(76)=-1.807, \mathrm{p}=.075$.

İlköğretim kurumlarında görev yapan öğretmenlerin pozitif psikolojik sermaye puanlarının öğretmenlerin branşlarına göre farklılı̆̆ının incelenmesi:Araştırma kapsamında incelenen ilköğretim kurumlarında görev yapan öğretmenlerin pozitif psikolojik sermaye puanlarının öğretmenlerin branşlarına göre ortalamalar arasındaki farklılığın istatistiksel olarak anlamlı olup olamdığını ortaya koymak amacıyla Bağımsız Örneklemler İçin T Testi yapılmıştır. İlköğretim kurumlarında görev yapan öğretmenlerin pozitif psikolojik sermaye puanlarının öğretmenlerin branşlarına göre ttesti sonuçları Tablo 13' de verilmiştir.

Tablo 13. İlköğretim Kurumlarnnda Görev Yapan Öğretmenlerin Pozitif Psikolojik Sermaye Puanlarmın Öğretmenlerin Branşlarnna Göre T-Testi Sonuçlar

\begin{tabular}{|c|c|c|c|c|c|c|}
\hline Branş & $\mathbf{N}$ & $\overline{\mathbf{x}}$ & SS & sd & $t$ & p \\
\hline \multicolumn{7}{|c|}{ Okul Öncesi ve } \\
\hline $\begin{array}{l}\text { Sinif Öğret- } \\
\text { menliği }\end{array}$ & 40 & 93.18 & 8.45 & 76 & -1.367 & .176 \\
\hline $\begin{array}{l}\text { Branş Öğgret- } \\
\text { menleri }\end{array}$ & 38 & 95.82 & 8.61 & & & \\
\hline
\end{tabular}

Tablo 13 incelendiğinde, ilköğretim kurumlarında görev yapan öğretmenlerin pozitif psikolojik sermaye puanları öğretmenlerin branşlarına göre anlamlı bir farklılık göstermemektedir, $\mathrm{t}(76)=-1.367, \mathrm{p}=.176$.

İlköğretim kurumlarnnda görev yapan öğretmenlerin pozitif psikolojik sermaye puanlarının öğretmenlerin görev sürelerine (deneyimlerine) göre farklılı̆̆ının incelenmesi: Araştırma kapsamında incelenen ilköğretim kurumlarında görev yapan öğretmenlerin pozitif psikolojik sermaye puanlarının öğretmenlerin görev sürelerine (deneyimlerine) göre ortalamalar arasındaki farklılığın istatistiksel olarak anlamlı olup olamdığını ortaya koymak amacıyla tek yönlü varyans analizi (ANOVA) yapılmıştır. Varyansların homojenliği varsayımını test etmek için Levene homojenlik testi gerçekleştirilmiştir ve sonuçları Tablo 14a'da verilmiştir. 
Tablo 14a. Öğretmenlerin Görev Sürlerine (Deneyimlerine) Göre Pozitif Psikolojik Sermaye Puanlarını Levene Homojenlik Testi Sonuçları

\begin{tabular}{llll}
\hline Levene & sd1 & sd2 & p \\
\hline .978 & 3 & 74 & .408 \\
\hline
\end{tabular}

Tablo 14a incelendiğinde varyansların homojen olduğu görülmektedir, Levene $=.978, \mathrm{p}=.408$. Bu durum göz önüne alınarak ANOVA $F$ testi kullanılmıştır (Pallant, 2016). İlköğretim öğretmenlerinin görev sürelerine (deneyimlerine) göre pozitif psikolojik sermaye algılarına ait betimsel istatistikler Tablo 3'te, görev sürelerine (deneyimlerine) göre farkl1lı̆g 1 gösteren ANOVA testi sonuçları Tablo 14b'de verilmiştir.

Tablo 14b. Pozitif Psikolojik Sermaye Puanlarnın Görev Süresine (Deneyimlerine) Göre ANOVA Sonuçları

\begin{tabular}{lllllll}
\hline Gruplar & Karelerin Toplamı sd & $\begin{array}{l}\text { Karelerin } \\
\text { Ortalaması }\end{array}$ & $\mathbf{F}$ & $\mathbf{p}$ & Anlamlı Fark \\
\hline Gruplar arası & 498.374 & 3 & 166.125 & 2.382 & .076 & - \\
Grup içi & 5161.010 & 74 & 69.743 & & & \\
Toplam & 5659.385 & 77 & & & & \\
\hline
\end{tabular}

Analiz sonuçları, pozitif psikolojik sermaye ortalama puanları arasındaki farkın öğretmenlerin görev sürelerine (deneyimlerine) göre anlamlı bir fark olmadığını göstermektedir, $\mathrm{F}(3,74)=2.382$, p=.076.

İlköğretim kurumlarında görev yapan öğretmenlerin pozitif psikolojik sermaye puanlarının öğretmenlerin pozitif psikoloji ile ilgili herhangi bir eğitim alma durumlarına göre farkhlığının incelenmesi: Araştırma kapsamında incelenen ilköğretim kurumlarında görev yapan öğretmenlerin pozitif psikolojik sermaye puanlarının öğretmenlerin pozitif psikoloji ile ilgili herhangi bir eğitim alma durumlarına göre ortalamalar arasındaki farklılığın istatistiksel olarak anlamlı olup olamdığını ortaya koymak amacıyla Bağımsız Örneklemler İçin T Testi yapılmıştır. İlköğretim kurumlarında görev yapan öğretmenlerin pozitif psikolojik sermaye puanlarının öğretmenlerin pozitif psikoloji ile ilgili herhangi bir eğitim alma durumlarına göre t-testi sonuçları Tablo 15'te verilmiştir. 
Tablo 15. İlköğretim Kurumlarnda Görev Yapan Öğretmenlerin Pozitif Psikolojik Sermaye Puanlarının Öğretmenlerin Pozitif Psikoloji İle İlgili Herhangi Bir Eğitim Alma Durumlarına Göre T-Testi Sonuçları

\begin{tabular}{|c|c|c|c|c|c|c|c|}
\hline $\begin{array}{l}\text { Pozitif Psikoloji } \\
\text { Eğitimi } \\
\end{array}$ & $\mathbf{N}$ & & $\overline{\mathbf{x}}$ & SS & sd & $t$ & $p$ \\
\hline Evet & 18 & 95.11 & & 9.36 & 76 & .364 & .717 \\
\hline Hayır & 60 & 94.27 & & 8.40 & & & \\
\hline
\end{tabular}

Tablo 15 incelendiğinde, ilköğretim kurumlarında görev yapan öğretmenlerin pozitif psikolojik sermaye puanları öğretmenlerin pozitif psikoloji ile ilgili herhangi bir eğitim alma durumlarına göre anlamlı bir farkl1l1k göstermemektedir, $\mathrm{t}(76)=0.364, \mathrm{p}=.717$.

İlköğretim kurumlarında görev yapan öğretmenlerin okul iklimi algı puanlar ile pozitif psikolojik sermaye puanlar arasındaki ilişkinin incelenmesi: lköğretim kurumlarında görev yapan öğretmenlerin okul iklimi algıları (Okul İklimi Ölçeği'nin ölçtüğü yapı ile) ile pozitif psikolojik sermaye algıları (Pozitif Psikolojik Sermaye Ölçeği'nin ölçtüğü yapı ile) arasındaki ilişkinin belirlenebilmesi amacıyla Pearson momentler çarpımı korelasyon katsayısı hesaplanmıştır. Hesaplama işlemine geçilmeden önce normallik, doğrusallık ve eş varyanslılık varsayımları kontrol edilmiştir. Yapılan analiz sonucunda ilköğretim öğretmenlerinin okul iklimi algıları ile pozitif psikolojik sermaye algıları arasında anlamlı bir ilişki olmadığı görülmüştür, $r=.198, n=78, p=.081$.

Araştırma sorularında ifade edilen ilköğretim öğretmenlerinin pozitif psikolojik sermaye alg1 düzeylerinin ilköğretim öğretmenlerinin okul iklimi algılarını anlamlı bir biçimde yordayıp yordamadığının belirlenmesini ifade eden basit doğrusal regresyon analizi yapılmamıştır. Çünkü herhangi iki değişken arasında regresyon denkleminin kurulabilmesinin ön şartlarından biri söz konusu iki değişken arasında anlamlı bir ilişkinin olmasıdır. Araştırmada da ilköğretim öğretmenlerinin pozitif psikolojik sermaye algıları ile okul iklimi algıları arasında anlamlı bir ilişki olmadığ görülmüştür (Tabachnick ve Fidell, 2013). 


\section{Tartışma ve Sonuç}

Okul iklimi, genel olarak okul yaşamının fiziki, sosyal ve duygusal bağlamına yönelik psikolojik algılamalar bütünüdür. Okulda ki mevcut çalışma iklimi, okul paydaşları arasındaki fiziki, sosyal ve duygusal etkileşim ve iletişimin niteliğine göre olumlu ya da olumsuz olarak etkilenmektedir. Okulun örgütsel kalitesi, verimliliği ve başarısı açısından öğretmenler, okul iklimi oluşturulabilmesi açısından tanımlayıcı özelliğe sahiptirler. Her birey farklı bir kişilik yapısına sahiptir. Bu nedenle, her okulun kendine ait bir işleyişi, yönetim şekli, çalışan profili ve kendine özgün iklimi vardır. Kurumsal misyon ve vizyon göre değişik tutum ve davranış sergime eğiliminde olan öğretmenlerin çalışma performansları da doğrusal olarak azalabilir. Yapılan çalışmalarda, planlı ve sistemli olarak yapılandırılan okul iklimi faaliyetlerinin öğrencilerin kişisel gelişimleri ve akademik başarısı üzerinde etkisi olduğu ileri sürülmüştür. Bununla beraber, öğretmenlerin pozitif geri bildirimlerinin öğrencilerin öz yeterlilik algılarını pozitif olarak etkilediği ve öğrencilerin akademik başarılarının doğrusal olarak yükseldiği gözlemlenmiştir (Hoge, Smith ve Hanson, 1990; Osterman, 2000; BlumMcNeely ve Rinehart, 2002). Pozitif okul iklimi öğretmenlerin, öğretim performanslarındaki pozitif etkisinin gözlemlendiği diğer bir çalışmada ise, verimli ve etkili öğretim performansının öğrencilerin akademik başarıları üzerindeki etkisi saptanmıştır (Talbert, 2002).

$\mathrm{Bu}$ noktada, okul iklimine göre değişik tutum ve davranış sergime eğiliminde olan öğretmenlerin performansları da doğrusal olarak azalması öğrenci başarısını ve öğrenme motivasyonu negatif olarak etkileyebileceği gibi kurumsal işleyiş ve verimliliğe de zarar verebilir. Yapılan araştırma sonucuna göre, ilköğretim kurumlarında görev yapan öğretmenlerin okul iklimi algılarının yüksek olduğu söylenebilir. Yapılan çalışmanın diğer öğretim kademelerindeki tüm branş öğretmenleri üzerinde yapılaması öngörülebilir. Bununla birlikte, okul iklimi algısının öğretmenlerin, cinsiyet, yaş, görev süresi ve branşlarına göre farklılaşmamaktadır. Bu sonuç, okul ikliminin demografik değişkenlerden bağımsız olarak ortak bir değer, tutum ve davranış çerçevesinde oluşturulduğu savını destekleyebilir. 
Yapılan çalışmalar sonucunda, psikolojik sermaye algısı yüksek olan bireylerin zorluklarla mücadele etme eğilimlerinin psikolojik sermaye alg1sı düşük olan bireylere göre daha yüksek olduğu ileri sürülmüştür. Bununla birlikte, psikolojik sermaye ile öznel iyi oluş arasında pozitif bir ilişki saptanmıştır (Qingquan ve Zongkui, 2009; Khan, Siraj ve Li, 2011). Bu noktada, psikolojik sermaye algı düzeyi yüksek olan öğretmenlerin okul paydaşları ile arasındaki etkileşim ve iletişimin niteliğinin etkin ve verimli olacağı öne sürülebilir. Bu çalışmada, ilköğretim kurumlarında görev yapan öğretmenlerin pozitif psikolojik sermaye algı düzeylerinin yüksek olduğu söylenebilir. Dolayısı ile ilköğretim kurumunda görev yapmakta olan öğretmenlerin zorluklarla mücadele etme eğilimlerinin ve öznel iyi oluşlarının yüksek olduğu ileri sürülebilir. Geleceğe yönelik yapılacak çalışmalarda, ilköğretim kurumlarında görev yapan öğretmenlerin pozitif psikolojik sermaye algı düzeyleri ile çatışma çözümleme ve stres ile başa çıma becerileri arasındaki ilişkinin incelenmesi öngörülebilir. Bu çalışmada, ilköğretim kurumlarında görev yapmakta olan öğretmenlerin pozitif psikolojik sermaye düzeyleri demografik değişkenlere göre anlamlı bir fark göstermemiştir.

İlköğretim kurumlarında görev yapan öğretmenlerin okul iklimi algıları (Okul İklimi Ölçeği'nin ölçtüğü yapı ile) ile pozitif psikolojik sermaye algıları (Pozitif Psikolojik Sermaye Ölçeği'nin ölçtügü yapı ile) arasında korelasyonel anlamda anlamlı bir ilişki olmadığı görülmüştür. Buna karşın, ilköğretim öğretmenlerinin okul iklimi alg1 düzeyleri ile psikolojik sermaye alg1 düzeyleri yüksektir. Bu nedenle, bu yapılar arasında ilişki olmamasına karşın, yapılar bir biri içinde yuvalamış olabilir. Çünkü pozitif psikolojinin ortaya koymuş olduğu kavramlar okul iklimini oluşturabilecek kavramlar ile örtüşmektedir. Ayrıca istatistiksel olarak incelendiğinde söz konusu p değerinin .08 olduğu görülmektedir. $\mathrm{Bu}$ durum belirlenen alfa katsayısı ve örneklem ile ilgili olabilecek durumları düşündürmektedir. Bu nedenle daha geniş çaplı ve farklı örneklemlerde çalışılması öngörülebilir. 


\section{EXTENDED ABSTRACT \\ The Predictive Power of Positive Psychological Capital on School Climate: Primary Teachers' Examination \\ *}

Ali Akdoğan

Final University

School climate refers psychological perception of school community. School climate socially, emotionally, and physically affect the school community. School climate stimulates as a descriptive domain of school effectiveness that fosters the school community's attitudes, values, and behavior. Every individual born as an unique thus, each school has been consisted of different individuals whose attitudes, values and behavior may be different. School climate may define as making common good in positive and collaborative climate. Mainly due to the creating positive school climate, the school community members must share norms, values, beliefs, expectations, traditions, and interactions that make up the school community. Thus, the members of the school community need to have psychological capital to create and enhance positive school climate. Psychological capital refers to a set of resources a person can use to help improve their performance on the job and their success. It includes four different resources - self-efficacy, optimism, hope, and resilience. collaboration and instructional innovation had the most powerful effects. In the school community, decision making is positively related to community memebers' interaction, thus psychological capital was a key mediator of the effects that school climate. Mainly due to positive relationship of school climate and psychological capital, the study was conducted on the predictive power of positive psychological capital on school climate. It is mostly important that how primary school teachers' attitudes, values and behavior affect the school community especially students. Primary school settings need to more attention to examine whether primary school teachers develop their school climate, and whether school climate would increase positive psychological capital levels. Effective school studies coundected on 
positive school climates showed that were some key components of organizational culture and school climate including academic achievement, relationship among school community, decision making, collaborative working, doing their job passionately, having a good sense of humour, making students active, cooperating with colleagues, dealing with students' problems, and being democratic, polite and patient . School climte refers psychological perception of school community. Thus, the members of the school community need to have psychological capital to create and enhance positive school climate.

The study aimed to investiagate the school cilmate and its relationship to positive psychological capital among primary school teachers. The study was conducted to determine whether primary school teachers develop their school climate, and whether school climate would increase positive psychological capital levels. The participants of the study were composed of 114 primary school teacher were selected randomly around Istanbul. The data were based on quantitative data. For the data analysis Pearson Product-Moment Correlation, and a series of ANOVA test were utilized. The results revealed that there was no a pozitif significant correlation between percieved school climate and positive psychological capital $(\mathrm{r}=.198, \mathrm{n}=78, \mathrm{p}=.081)$. Meanwhile, the study showed that primary school teachers' school climate perception and positive psychological capital perceptions were high $\left(\mathrm{X}^{-}=94.58\right)$. In addition, there was no significant difference between positive psychological capital perceptions of primary school teachers and demographic variables. Thus, it could be suggested that the school climate and psychological capital may be consist of within eachother. The school climate consisted of subdimension which were strongly related with psychological capital. Moreover, school climate perceptions of primary school teachers were not differented according to variables such as a,gender, working experiences and their major.Thus, school climate could be indepented value that was created by school community with common attitudes and behavior. The primary school teachers whose school climate perceptions' were very high those could be stimulate friendly relationship around the school community also it could be said that primary school teachers could be challenge with struggles while reducing stress. 
Mainly due to the result of higher perception of school climate of primary school teachers may affect school climate,therefore, students' academic achievement may be higher and individual development needs of them may be satisfied. Pozitive feedback from school communities may stimulate pozitive school climate. In addition, psychological capital perceptions of primary school teachers were high and not differented according to variables such as a,gender, working experiences and their major.Thus, psychological capital could be indepented value that was created by school community with common attitudes and behavior. However, psychological capital could differented according to age of primary school teachers. Primary school teachers who were among the ages of 40-64 were more higher perception of psychological capital than primary school teachers who were amonung the ages of 20-39. It could be said that primary school teachers' experiences may enhance perception of psychological capital.

Key Words: school climate, positive psychological capital, organizational efficacy, academic achievement, primary school teachers

\section{Kaynakça / References}

Akçay, V. (2014). Psikolojik Sermaye Ölçeği uyarlaması: Geçerlik ve Güvenirlik çalışması. Üçüncü Sektör Sosyal Ekonomi, 49(2), 72-84.

Anderson, C. (1982). The Searchh for school climate: A review of the research. Review of Educational Research, 18(2), 368-420.

Bandura, A. (1997). Self-efficacy: The exercise of control. New York: Freeman.

Boud, D., Lankford, H., Grossman, P., Loeb, S. ve Wyckoff, J. (2006). How changes in entry requirements alter the teacher workforce and affect student achievement. Education Finance and Policy, 48(2), 176-216.

Büyüköztürk, Ş., Kılıç Çakmak, E., Akgün, Ö., Karadeniz, Ş. ve Demirel, F. (2016). Bilimsel araştırma yöntemleri (21. b.). Ankara: Pegem Akademi Yayıncilık. doi:10.14527/9789944919289.

Canlı, S., Demirtaş, H. ve Özer, N. (2018). Okul İklimi Ölçeğinin geçerlik ve güvenirlik çalışması [A Validity and Reliability Study for the School Climate Scale]. Illköğretim Online [Elementary Education Online], 17(4), 1797-1811. doi:10.17051/ilkonline.2019.506842.

Cohen, J. ve Michelii, N. (2006). Evaluating school climate: Promoting the skills, dispositions and a climate for democracy. National Network for Educational Renewal News, 74(8), 2-4. 
Freiberg, H. (1999). School climate: Measuring, improving and sustaining healthy learning environments. Philadelphia: Falmer Press.

Greenberg, M., Weissberg, R., O'Brien, M., Zins, J., Fredericks, L. ve Resnik, H. (2003). Enhancing school-based prevention and youth development through coordinated social, emotional, and academic learning. American Psychologist, 3(1),466-474.

Haplin, A. ve Croft, D. (1963). Organizational climate of schools. Chicago: MidwestAdministration Center, University of Chicago.

Hoge, D., Smit, E. ve Hanson, S. (1990). School experiences predicting changes in self-esteem of sixth- and seventh-grade students. Journal of Educational Psychology, 82,117-127.

Homana, G., Barber, C. ve Torney-Putra, J. (2006). Background on the school citizenship education climate assessment. Denver: Education Commission of the States.

Kasen, S., Johnson, P. ve Cohen, P. (1990). The impact of social emotional climate on student psychopathology. Journal of Abnormal Child Psycho$\log y, 5,165-177$.

Khan, A., Siraj, S. ve Li, L. (2011). Role of positive psychological strengths and big five personality traits in coping mechanism of university students. International Conference on Humanities (s.210-215). Society and Culture. http://www.ipedr.com/vol20/41-ICHSC2011-M10027.pdf adresinden alınd1. 20.09.2021.

Kline, R. (2016). Principles and practice of structural equation modeling. New York: The Guilford Press.

Luthans, F., Youssef, C. ve Avolio, B. (2007). Psychological capital: Developing the human competitive edge. New York: Oxford University Press.

Luthas, F. (2002). The need for and meaning of positive organizational behavior. Journal of Organizational Behavior, 23(2),695-706.

Malone, L. (2010). Individual differences and stress reactions as predictors of performance in pilot trainees. Available from ProQuest Dissertations and Theses database. https://krex.k-state.edu/dspace/handle/2097/4131.20.08.2021

McMillan, D. (1996). Sense of community. Journal of Community Psychology, 24(4), 315-325.

Pallant, J. (2016). SPSS survival manual (6. b.). New York: McGraw Hill Education. 
Peterson, S. ve Luthans, F. (2003). The positive impact and development of hopeful leaders. Leadership and Organization Development Journal, 24,36-31.

Seligman, M. (2002). Authentic happiness. New York: Free Press.

Tabachnick, B. ve Fidell, L. (2013). Using multivariate statistics. New York: Pearson Education.

\section{Kaynakça Bilgisi / Citation Information}

Akdoğan, A. (2021). İlköğretim öğretmenlerinin pozitif psikolojik sermaye algıları düzeylerinin okul iklimi üzerindeki etkisinin incelenmesi. OPUS-Uluslararası Toplum Araştırmaları Dergisi, 18(44), 7721-7748. DOI: 10.26466/opus. 934995. 